Article

\title{
The Interpretation of Adjective-N Sequences in Spanish Heritage
}

\author{
José Camacho \\ Linguistics Department, Department of Spanish and Portuguese, Rutgers University, New Brunswick, NJ 08901, \\ USA; jcamacho@rutgers.edu
}

Received: 6 October 2018; Accepted: 19 November 2018; Published: 23 November 2018

check for updates

\begin{abstract}
Adjectives appear predominantly postnominally in Spanish, and when prenominal, cannot be interpreted as restrictive. We explore whether heritage speakers of Spanish have the same interpretive and ordering restriction as monolinguals. Twenty-two US college-age heritage speakers and 17 college-age monolinguals from Peru completed a rating task that manipulated word order and interpretation. Items varied in word order (Adj-N/N-Adj) and interpretation (restrictive-only, color and nationality adjectives, and ambiguous adjectives, restrictive and non-restrictive), all framed within a context that favored a restrictive interpretation. Both groups judged Adj-N orders lower than N-Adj orders, and restrictive adjectives lower in prenominal position than ambiguous adjectives. Consequently, we argue that heritage speakers (HS) have the relevant knowledge regarding word order and interpretation, and the interactions among the two properties. We propose a syntactic representation involving NP-raising for both groups, and suggest that in some cases, the higher copy of the NP is deleted, resulting in the linear order Adj-N. We also argue that this analysis may explain the range of individual variation across heritage speakers.
\end{abstract}

Keywords: adjective word order; heritage speakers; restrictive adjective; DP-structure; copy-theory of movement; heritage speaker variation

\section{Introduction}

The grammar of adjectives differs systematically in Romance and Germanic languages, as many researchers have noted (cf. Bernstein 1991, 1993a, 1993b; Cinque 1994, 2010; Lamarche 1991; Sánchez 1996; among others). First, the default adjectival position varies: English/Germanic languages have prenominal as the default (red leaf), whereas Romance languages have the opposite default order: 'hoja roja leaf red'. However, both language families still allow for a marked position. ${ }^{1}$ Second, the interpretive possibilities go hand-in-hand with the default positioning of the adjective (Bello 1847; Bolinger 1967). Prenominal adjectives in Romance are semantically more constrained than postnominal ones, and the postnominal adjectives are semantically more constrained than prenominal ones in Germanic. Since the range of semantic interpretations is large (cf. Cinque 2010), in this study, we focus on the two important ones: restrictive or non-restrictive interpretations. In the prenominal position, English allows for both, as illustrated in example (1). In contrast, a postnominal adjective is not only stylistically more marked, but it is also semantically unambiguous, i.e., it can only have the restrictive interpretation, as seen in example (2).

1 Interestingly, while the generalizations about "Romance" and "Germanic" are full of exceptions, this word order difference seems to be robust for all of the languages involved. 
English:

1 All of the unsuitable acts were condemned Adj-N, ambiguous
a. Restrictive interpretation: 'only unsuitable acts were condemned.'

(Cinque 2010, p. 7)

b. Non-restrictive: 'all of the acts were condemned and unsuitable.'

2 Every word unsuitable was deleted N-Adj, only restrictive

a. Restrictive interpretation: 'only unsuitable words were deleted.'

In Spanish, on the other hand, the prenominal position is more marked, both stylistically and semantically, as example (3) shows. ${ }^{2}$ Conversely, the postnominal position is stylistically less marked, and semantically ambiguous, as seen in example (4).

Spanish:

3. Todos los estúpidos discursos fueron condenado Adj-N, only non-restrictive all the stupid speeches were condemned

'All the stupid words were condemned.'

a. Non-restrictive interpretation: 'all of the words were condemned, and they were stupid'

4. Todos los discursos estúpidos fueron condenados N-Adj, ambiguous all the speeches stupid were condemned

'All the stupid speeches were condemned.'

a. Restrictive interpretation: 'only speeches that were stupid were condemned.'

b. Non-restrictive interpretation: 'all of the speeches were condemned, and they were stupid.'

We can define a restrictive interpretation of the adjective as follows: when an N-Adj sequence refers to a subset of the referents of the $\mathrm{N}$, the adjective is restrictive. In this sense, restrictive adjectives are extensional. In contrast, when the reference of the $\mathrm{N}$ is not reduced, the adjective is non-restrictive, rather it targets some aspect of the concept associated with the N. For example, gran profesor 'great professor' modifies the concept of being a professor, whereas profesor grande 'big professor' restricts the membership of the set of professors to a subset. ${ }^{3}$

A related semantic classification involves intersective vs. non-intersective interpretations. The first type indicates that the reference of $\mathrm{Adj}-\mathrm{N}$ is the intersection between the reference of the adjective and the reference of the $\mathrm{N}$ : the meaning of white in white horse is intersective if $\|$ white horse $\|=\|$ white $\|\cap\|$ horse $\|$ (i.e., the intersection of the set of white things and horses) (cf. Demonte 1999a, 1999b; Kamp and Partee 1995). In contrast, non-intersective adjectives are relative: a small horse can be 'small for a horse' (but still large compared to a human). As Roger Schwarzschild (personal communication) points out, intersectivity refers to the semantic meaning of the adjective, whereas restrictive interpretations are syntactically/contextually determined, e.g., that charming wife of yours could be used restrictively if I have two wives, but non-restrictively if I only have one. In fact, restrictive and intersective adjectives are grouped together by Cinque (2010) as indirect modifiers, whereas non-restrictive and non-intersective ones are grouped together as direct modifiers. However, it should be clear that not all restrictive adjectives are necessarily intersective.

The ordering differences between adjectives in Romance and Germanic have been analyzed in two general ways: (a) As a consequence of N-raising (cf. Bernstein 1993a, 1993b; Cinque 1994), and (b) as a consequence of XP-raising analysis (cf. Cinque 2010; Sánchez 1996). For Cinque (2010), adjectives are generated in different functional projections (specialized for meaning) that are underlyingly identical

2 Some adjectives like gran 'great' cannot restrict the set of referents, and they can only appear in a prenominal position. See Demonte (2008).

3 An anonymous reviewer suggests that only predicative adjectives are restrictive. It is possible that predicativity is connected with the reduced relative-clause position in Cinque's (2010) analysis, see below. 
across Romance and Germanic, and word order differences stem from additional movements (both the $\mathrm{N}$-movement and XP movement, see below).

Heritage speakers (HS) of Spanish, whose first language is Spanish, but who grew up in the US and have become dominant in English seem to produce the word order of English, as in example (5), which would be grammatical in monolingual Spanish, but would only have the non-restrictive interpretation (as in example (3)a above).

$$
\begin{array}{lll}
\text { 5. a. Las inapropiadas } & \text { palabras } \\
& \text { The inappropriate words } \\
& \text { 'The inappropriate words.' }
\end{array}
$$

In this paper, we explored whether this observation holds systematically, that is, if HS speakers of Spanish had different word order patterns for adjectives than monolingual Spanish speakers, and whether the interpretation of adjectives in HS was different from those of the monolingual counterparts. Specifically, if HS speakers accept the Adj-N word order more than monolinguals, does that also mean that their interpretation is less restricted? Or is the Adj-N word order independent of the interpretation?

\subsection{The Syntax and Semantics of Adjectives in Spanish and English}

A large body of research on the internal structure of Determiner Phrases (DPs) has attempted to capture the parametric differences between Romance-type DPs, which predominantly have the order $\mathrm{N}$-Adj, and Germanic-type DPs, which have the opposite word order, as described earlier. We can distinguish three basic proposals that share the assumption that Germanic and Romance have a common underlying order (cf. Alexiadou 2014). The first one proposes raising of the adjective from the postnominal to prenominal position (cf. Abeillé and Godard 1999; Androutsopoulou 2000; Laenzlinger 2004; Larson and Marusic 2004); the second one, proposes N-raising (cf. Bernstein 1993a; Cinque 1994) and the third one, proposes XP (NP) raising (cf. Cinque 2010; Laenzlinger 2004; Shlonsky 2004).

The adjective movement analysis is based on certain distributional asymmetries between the prenominal and postnominal adjectives. For example, Demonte (1999b) notes that prenominal

\begin{tabular}{|c|c|c|c|c|c|}
\hline 6. a. & $\begin{array}{l}\text { Excelente/ } \\
\text { excellent.SG/ } \\
\text { 'Excellent view }\end{array}$ & $\begin{array}{l}\text { *excelente-s } \\
\text { excellent-PL } \\
\text { d attention.' }\end{array}$ & $\begin{array}{l}\text { vist-a } \\
\text { view-F }\end{array}$ & $\begin{array}{l}\mathrm{y} \\
\text { and }\end{array}$ & $\begin{array}{l}\text { atención } \\
\text { attention.F }\end{array}$ \\
\hline b. & $\begin{array}{l}\text { Vist-a } \\
\text { view-F }\end{array}$ & $\begin{array}{l}\mathrm{y} \\
\text { and }\end{array}$ & $\begin{array}{l}\text { atención } \\
\text { attention.F }\end{array}$ & $\begin{array}{l}\text { excelente-s/ } \\
\text { excellent-PL/ }\end{array}$ & $\begin{array}{l}\text { *excelente } \\
\text { excellent.SG }\end{array}$ \\
\hline
\end{tabular}
adjectives modifying two coordinated NPs can show an agreement mismatch that is not possible in the postnominal position: ${ }^{4}$

If the adjective moves in an across-the-board fashion from each of the conjuncts in the postnominal position, then the pattern in (6)a follows that the adjective is never plural, and therefore, there is no source plural morphology prenominally. In (6)b, on the other hand, no movement takes place, and the adjective is merged with the full conjoined structure, triggering the obligatory plural. In this analysis, the fact that the prenominal positions are not always possible must follow from the fact that the movement trigger is missing (or that raising is blocked by some structural constraint).

Initially proposed by Bernstein (1991), the N-raising analysis suggests that nouns move to a higher position in Romance than in Germanic, and that this difference relates to a difference in the functional projections, i.e., whereas Romance languages have overt and active person and number features, Germanic does not, and these features trigger the N-movement (cf. Bernstein 1993b; Cinque 1994;

4 I follow the Leipzig glossing conventions: discrete morphemes (- $a$ ' $\mathrm{F}^{\prime},-s$ 'PL') are separated by a hyphen, but feature content not ascribable to any specific morpheme is separated by a period (atención.F). 
Picallo 1991). However, Lamarche (1991) had already noted that the mirror-image ordering of adjectives in Germanic and Romance is unexpected if the only difference between the two languages involves N-raising (cf. Cinque (2010) for the extended discussion of further problems for the N-raising analysis). Additionally, as noted by Sánchez (1996), examples like (7)b challenge this analysis because [mesa de madera] 'wooden table' does not seem to be a single head raising across the adjective. ${ }^{5}$

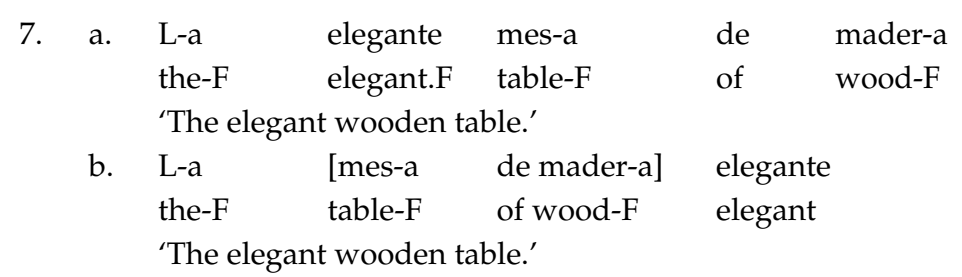

Cinque (2010) attempts to derive the differences between Germanic and Romance adjective ordering from a common underlying structure for DPs (see example (8)). As in previous analyses, he derives the word order differences through phrasal movement. Specifically, the DP contains a series of functional projections (FP1, FP2, FP3), which are associated with different interpretations and/or different types of adjectives. For example, the top projection (FP1) hosts reduced relative clauses, the source of intersective and restrictive readings. F2, F3, and F4, on the other hand, are the source of so-called "direct modifiers" (cf. Sproat and Shih 1991), i.e., individual-level, non-restrictive, non-intersective adjectives.

\section{8. [DP [FP1 RelCl [FP2 AP1 [FP3 AP2 ... NP]]]]}

Intersective adjectives, such as red in red car denote the intersection between the denotation of the A and $\mathrm{N}$, formally, $\|\mathrm{A} . \mathrm{N}\|=\|\mathrm{A}\| \cap\|\mathrm{N}\|$. Restrictive readings (also called extensional), on the other hand, perform a similar function, depending on the context. For example, your charming husband would be restrictive if there are several husbands, but non-restrictive if there is only a single husband. In this sense, restrictivity and intersectivity perform similar functions, but the former notion is pragmatic, whereas the latter is semantic. Additionally, there are restrictive adjectives that are not intersective, such as bueno 'good' (evaluative) or grande 'big' (relational). This confirms that the notion of restrictiveness is clearly independent of other semantic categories.

Whenever two adjectives follow $\mathrm{N}$ in Romance, the outermost one is usually intersective, restrictive, whereas the inner one is non-intersective, non-restrictive. This is particularly true when the second one is focused. In contrast, the opposite holds for English.

For Cinque, this pattern suggests that restrictive modifiers are located high in the structure (roughly as suggested by the word order in example (10)a), and that different movements derive the word order and the patterns observed for Romance. Specifically, given the proposed common underlying structure in example (8), restrictive and intersective interpretations, which are a subset of indirect modification adjectives, are connected to the reduced relative clause position F1. In English, no movements take place, so we expect the first adjective to be restrictive, the second adjective to be non-restrictive, and both precede N (as seen in example (11)b). In Romance, on the other hand,

5 Several researchers have connected N-raising to a strong feature related to an overt morphological trigger (cf. Picallo 1991; Ritter 1991; Rothman et al. 2010). For example, Walloon lacks noun raising and number agreement, whereas French has both noun raising and number agreement (cf. Bernstein 1993a). However, Greek has overt number morphology but no raising (cf. Alexiadou 2001, p. 223):

i. *To spiti meghalo
the house big
ii. To meghalo spiti
the big house
'The big house.'


the constituent FP4 (which contains the NP, possible complements, and direct modifiers) moves to the specifier of FP1, and for this reason, the restrictive modifiers are always linearly last, as seen in example (11)a. ${ }^{6}$

9. a. $\mathrm{Su}$ acto inapropiado his/her act unsuitable MÁS INAPROPIADO (non-restrictive $>$ restrictive)
most unsuitable 'His/her most unsuitable unsuitable act.'
b. $\quad *$ Su acto MÁS INAPROPIADO inapropiado $\left({ }^{*}\right.$ restrictive $>$ non-restrictive $)$ his/her act most unsuitable unsuitable

10. a. His MOST UNSUITABLE unsuitable acts (restrictive $>$ non-restrictive, Cinque 2010, p. 9)

b. $\quad{ }^{*}$ His unsuitable MOST UNSUITABLE acts ( ${ }^{*}$ non-restrictive $>$ restrictive)

a. Spanish

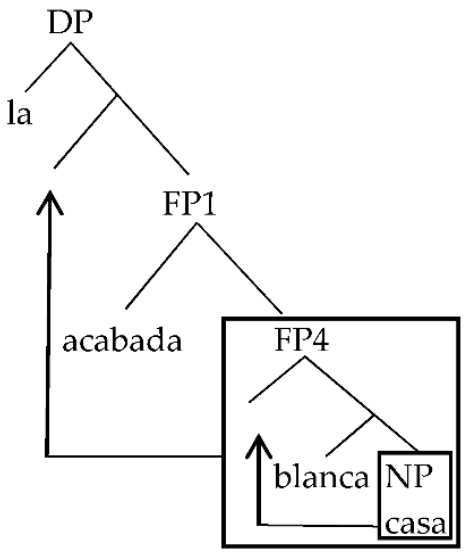

b. English

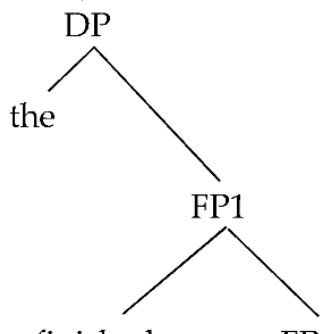

finished

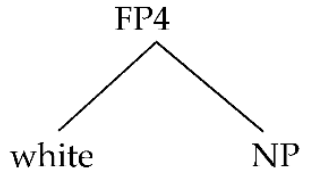

house

While this analysis handles the basic generalizations, it is well known that certain adjectives are ambiguous depending on the syntactic position, whereas others can only appear in one position and are unambiguous. Such are nationality adjectives (cf. (12)a) and color adjectives (cf. (12)b). The latter are possible in the Adj-N order only in a highly marked register, and they are forced into an intensional/non-restrictive reading. ${ }^{7}$

\begin{tabular}{|c|c|c|c|c|c|c|}
\hline \multirow[t]{2}{*}{ 12. a. } & $\begin{array}{l}\text { El.M } \\
\text { the.M }\end{array}$ & $\begin{array}{l}\text { embajador.M } \\
\text { ambassador.M }\end{array}$ & $\begin{array}{l}\text { mexican-o/ } \\
\text { Mexican-M/ }\end{array}$ & $\begin{array}{l}{ }^{*} \mathrm{el} \\
\text { the.M }\end{array}$ & $\begin{array}{l}\text { mexican-o } \\
\text { Mexican-M }\end{array}$ & $\begin{array}{l}\text { embajador } \\
\text { ambassador.M }\end{array}$ \\
\hline & 'The $\mathrm{M}$ & abassador.' & & & & \\
\hline b. & $\begin{array}{l}\text { L-a } \\
\text { the-F }\end{array}$ & $\begin{array}{l}\text { biciclet-a } \\
\text { bicycle-F }\end{array}$ & $\begin{array}{l}\text { blanc-a/ } \\
\text { white-F/ }\end{array}$ & $\begin{array}{l}\# 1-\mathrm{a} \\
\text { the-F }\end{array}$ & $\begin{array}{l}\text { blanc-a } \\
\text { white-F }\end{array}$ & $\begin{array}{l}\text { biciclet-a } \\
\text { bicycle-F }\end{array}$ \\
\hline
\end{tabular}

6 Cinque (2010) explicitly states that the indirect modifiers always follow any combination of NP + direct modifiers, and this is a consequence of movement higher than FP2. An anonymous reviewer notes that this may be due to focus assignment, since focused elements are assigned nuclear stress, which is generally DP-final.

7 An anonymous reviewer rightly notes that examples like (i-ii) challenge Cinque's analysis. In example (i), the postnominal adjective is restrictive, and by assumption the NP would raise higher than FP1, but there is a PP complement. One possible solution would be that the PP complement is generated higher than the direct modifiers, but lower than the reduced relative-clause position. This intermediate constituent is the one that raises passed FP1.
i. Las palabras inapropriadasdel inappropriate of-the conferenciante fueron
speaker were censuradas the censured words
ii. Las inapropiadas palabras del
of-the the inappropriate words of-the
'The speaker's inappropriate words were censured' conferenciante fueron censuradas speaker were censured 
Other adjectives like hermoso 'beautiful', imaginario 'imaginary' are ambiguous, i.e., in a postnominal position they can be extensional or intensional, and in a prenominal position, they are only intensional, as seen in example (13). In the first example, the adjective hermosa 'beautiful' modifies the concept of a song, whereas in the second one, it could either modify the concept or separate the referent of that particular song as opposed to others. While an NP-movement analysis can derive the differences in word order, these contrasts suggest that the prenominal and postnominal hermoso 'beautiful' must have different positions, otherwise one would not expect NP-movement to change the interpretation by itself.

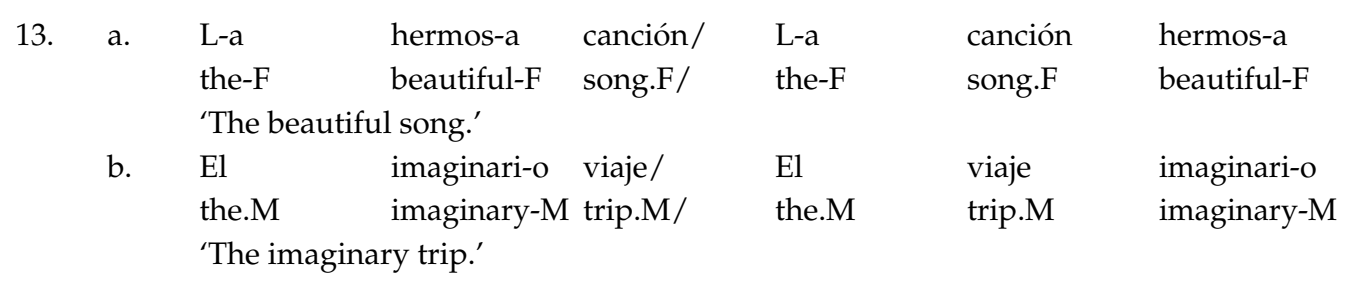

Thus, we assume that a prenominal hermosa 'beautiful' can occupy two positions, i.e., when it is extensional, it will appear in FP1 as in example (11)a, but when it is intensional, it occupies a lower position, in FP4. In sum, we have the following generalizations, following Cinque's (2010) analysis.

Adjectival interpretation and syntactic position correlation:

14. a.

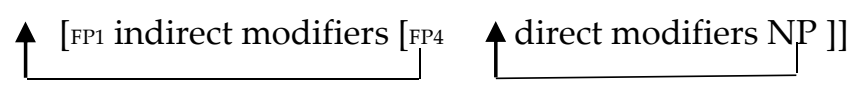

b. Certain adjectives (hermoso 'beautiful', imaginario 'imaginary') are ambiguous: they can appear in FP1 or FP4.

Other adjectives (mexicano 'Mexican', blanco 'white') are unambiguous: they are indirect

c. modifiers in a high position, and the NP must raise higher.

The word-order and the interpretation correlation follow from the first generalization, but the third one presumably follows from the meaning of those adjectives, i.e., in a low position they would not yield the right semantic interpretation. For this study's purposes, it was simply assumed that they are lexically specified as indirect.

The observed correlation between the interpretation and word order raises a question about the interpretation of examples, such as example (5), las inapropiadas palabras 'the unsuitable words' is in the HS grammar. One possibility is that prenominal adjectives are ambiguous in HS, as they are in English. According to this option, prenominal adjectives occupy two positions (FP1 and FP4), but the NP does not raise.

\subsection{Previous Studies}

As far as I am aware, most studies on the position of adjectives in a Romance language spoken by bilingual speakers have been done with adult L2 learners. All of them showed that advanced learners can learn the syntactic distribution (i.e., the positional restrictions), and the association between position and interpretation. Intermediate learners, on the other hand, had the following properties: first, their responses showed a tendency towards the target pattern, second, those responses were statistically different from those of the targets, and third, in some cases, they showed L1 influence, but in others, the responses were novel because they were not possible in either of the monolingual grammars.

Parodi et al. (2004) (originally circulated in 1997) compared the L2 acquisition of several properties of DPs in German by speakers of Korean, Turkish, and Romance. Regarding adjective word order, they noted that speakers of Korean and Turkish produced the target order (Adj-N) because of a weak NUM feature in their L1 (which does not trigger N-raising). Romance language speakers, on the other hand, showed a varying degree of non-target N-Adj (from $0 \%$ to $37.5 \%$ ) due to the strong NUM 
feature that forced N-raising in the L1. Gess and Herschensohn (2001) found a similar pattern of acquisition for L2-French/L1-English learners, who went from 34\% accuracy to $100 \%$ accuracy in an elicited production task. Bruhn de Garavito and White's (2002) study included an elicited production experiment with L1-French/L2-Spanish high school students, who showed N-Adj as the predominant word order.

Androutsopoulou et al. (2008) focused on the acquisition of evaluative adjectives (good, nice, etc.) by L2-Spanish/L1-French learners. Their study compared the acquisition of word order properties of three different types of adjectives. First, evaluative adjectives are uniformly possible prenominally in Spanish but not in French, so their study compared six adjectives that could appear prenominally in both languages to six adjectives that were not possible prenominally in French. Second, non-evaluative adjectives with a similar split to the previous type, and third, adjectives that are not possible prenominally in either language. Androutsopoulou et al. $(2008$, p. 10) concluded that "prenominal adjectives are a source of confusion for L2 learners of Spanish," primarily for the intermediate group. Advanced learners, on the other hand, fell back onto L2 patterns. Learners also showed different sensitivities to different adjective-types, so that low adjectives (the third type) were strongly disallowed in a prenominal position, as expected. Based on these results, they concluded that [+interpretable] features are specified item by item in the interlanguage grammars. In this particular case, a Degree/Focus feature that triggers movement in Spanish is absent in the initial stages of the L2.

Anderson's $(2001,2008)$ research represents the first set of L2 studies that focus on the interaction between adjective position and semantic interpretation in L2-French/L1-English. Anderson (2008) included six groups of L2 learners (total $=100$ ) and two comparison groups: one of 30 English monolinguals and one of 27 French monolinguals. Participants judged sentences in two-word orders (Adj-N and N-Adj), presented in two contexts each: one favoring an intersective interpretation and another favoring a general non-intersective interpretation. To begin with, the monolingual French natives were sensitive to the different interpretations related to word-order, so that prenominal adjectives in non-intersective contexts were accepted $75 \%$ of the time, vs. adjectives in intersective contexts $(47 \%)$. Postnominal adjectives, on the other hand, were accepted $59 \%$ of the time in intersective contexts and $14 \%$ in non-intersective contexts. Clearly, non-intersective contexts were preferred in the Adj-N order.

Second and third year learners, on the other hand, did not show significant differences for any option. Fourth year and advanced learners did, i.e., the former group preferred intersective to non-intersective contexts in the N-Adj order, and the latter group showed statistically significant different preferences for non-intersective contexts in the N-Adj order and for intersective contexts in the Adj-N order. In sum, L2 learners established both the word-order pattern and the interpretive distinctions associated with the word-order differences. Intriguingly, the advanced learners showed a more categorical pattern than the monolingual comparison group.

Rothman et al. (2010) studied the L2-Spanish/L1-English acquisition of adjective word order (and the associated meaning distinctions). Their syntactic analysis of the parametric difference between Spanish and English assumed that person and number features (phi-features) were responsible for $\mathrm{N}$-raising in Spanish but not in English, hence for the different word orders. In their first task, participants were asked to select a semantic interpretation consistent with a sentence that included, either a prenominal or postnominal adjective. In their second task, participants were given a unique semantic context and asked to choose between a prenominal or postnominal adjective position consistent with that context.

Advanced learners (but not intermediate learners) chose the right semantic interpretation similar to the control group, and they also produced the right adjective order in the appropriate semantic context. Although intermediate learners did not show control-like patterns, they did show similar tendencies as that group. In fact, the mean results for the intermediate learners masked two distinct patterns: a subgroup whose performance was closer to the control group, and another subgroup that was closer to chance. 
In sum, previous research on the L2 acquisition of adjectival order suggests that both word order and semantic restrictions are already present at the intermediate level of L2 acquisition, and that they can be fully acquired by advanced L2-learners. Our study builds on this work by focusing on heritage speakers and adapting previous experimental insights on L2 acquisition of adjectives (cf. Anderson 2001, 2002, 2007, 2008; Androutsopoulou et al. 2008; Rothman et al. 2010). The main question is whether HS speakers will have a pattern closer to monolinguals or closer to early L2 learners with respect to semantically restricted adjective placement.

\subsection{Hypotheses}

As mentioned, we were interested in exploring whether HS speakers had a different distribution for adjectives than monolingual speakers. Given the results from previous L2-acquisition studies, we expected HS speakers to have similar overall word order patterns to those of monolingual Spanish speakers. However, given that the availability of Adj-N/N-Adj orders was related to semantic interpretation, it was an open question whether word-order patterns would be semantically constrained in the same way as they were for monolingual Spanish. Finally, were HS patterns amenable to the unified proposal in Cinque-like analysis, or did it provide evidence for separate sources for adjectives?

15. Hypothesis 1 (H1). HS will show similar overall N-Adj/Adj-N word order patterns as monolingual Spanish.

16. Hypothesis 2 (H2).

HS will show the appropriate semantic and interpretive restrictions associated with different word orders (Adj-N/N-Adj).

a. Restrictive-only adjectives will be preferred in the N-Adj order and dispreferred in Adj-N.

b. Ambiguous adjectives will also be preferred in the N-Adj order and dispreferred in Adj-N.

\section{Materials and Methods}

Following previous experimental work on L2 acquisition of adjectives (cf. Anderson 2002, 2007; Rothman et al. 2010), our experimental study fixed the context, so that only one interpretation (the restrictive reading) was consistent with the given discourse, as illustrated in example (17). ${ }^{8}$

$$
\begin{array}{cllll}
\text { 17. En la tienda había dos relojes } & \begin{array}{l}
\text { distintos } \\
\text { In the store had }
\end{array}
\end{array}
$$

'There were two different watches in the store.'

$\begin{array}{llllllll}\text { a. } & \text { El reloj } & \text { hermoso costaba } & \text { aproximadamente } & 100 & \text { dólares } & (\text { N-Adj, restrictive } \sqrt{ }) \\ & \text { the } & \text { watch beautiful cost } & \text { about } & 100 & \text { dollars } & \\ \text { b. } & \text { El hermoso reloj } & \text { costaba } & \text { aproximadamente } & 100 & \text { dólares } & \text { (Adj-N, restrictive } \times) \\ & \text { the beautiful watch cost } & \text { about } & 100 & \text { dollars } & \end{array}$

'The beautiful watch cost approximately 100 dollars.'

The task consisted of 15 adjectives in contextualized sentences preceded by a context that favored a restrictive reading, as illustrated in example (17). Each adjective was presented pre and postnominally (Adj-N and N-Adj), totaling 30 sentences. Two groups of adjectives were included: five strictly restrictive (intersective adjectives like rojo, 'red') and 10 whose interpretation depended on the position, like habilidoso 'skillful', which could only be restrictive postnominally. Of those 10 ambiguous adjectives, five had a different meaning in the prenominal position (gran 'great' vs. postnominal grande 'big', buena 'intense' vs. postnominal buena 'good', etc.). In this paper, we did not discuss the results from this distinction any further.

Additionally, 30 sentences where included as fillers, wherein they involved possessive structures with prenominal possessives (su casa 'his/her house'), postnominal possessives (la casa suya 'his/her

8 This study was conducted under the protocol "The syntax of adjectives inheritage speakers" (IRB\#E16-523) was approved by Rutgers University's Internal Review Board (IRB) on 29 February 2016. 
house'), or PP-possessives (la casa de ella 'her house'). Finally, four more sentences had a verb and a locative phrase, as seen in example (18.), which was intended to establish a base line for acceptability judgments.

18. Una señora mayor estaba delante de ella a lady older was in-front of her 'An old lady was in front of her.'

All experimental items were presented in randomized and counterbalanced order using the PsychoPy software (cf. Peirce 2009). Participants were presented with the context sentence on a computer screen, followed by the test sentence that appeared one word at a time (each word remained on screen $0.7 \mathrm{~s}$ and disappeared before the next word appeared). At the end of the test sentence, participants had to click on a scale of 1 to 5 (with the words "unacceptable" and "acceptable" written over the edges of the scale). Before beginning the actual experiment, participants did two rounds of practice (see Appendix A). Participants also filled out a linguistic background and a self-assessment of their language ability in Spanish (see Appendix B).

A total of 25 college-age HS of Spanish were recruited for the study. They completed the multiple-choice portion of the DELE ${ }^{9}$, which consisted of 30 items. Based on the DELE scores, three out of the 25 participants were removed because they obtained below $60 \%$ correct answers (two of them also self-rated their overall Spanish proficiency as 1 and 3 out of 4 , respectively). Average DELE score for the remaining participants was $85 \%$ (SD: 0.10). All remaining participants (22) were exposed to Spanish between birth and 5 years and were either born in the US or arrived shortly after. They attended K-12 schools in the US. They lived in a household where both parents were native speakers of Spanish and dominant in that language. All participants reported having English as their current dominant language, although the average self-rating in Spanish was 8.19 (on a scale from 0-10). Finally, the comparison group included 17 college-age students from Lima, Perú.

\section{Results}

In Figure 1, we can see the average ratings for the Adj-N, the N-Adj, and for the baseline sentences. The latter were not significantly different for the comparison group $(M=4.33, \mathrm{SD}=1.1)$ than for the HS $(M=4.48, S D=0.9)$. As expected, both groups had higher ratings for the N-Adj $(M=3.87)$ than for the Adj-N $(M=3.05)$. Additionally, the HS group rated all categories slightly higher than the comparison group, as seen in Figure 1.

9 DELE (Diploma de español como lengua extranjera, Spanish as a foreign language Diploma) is the standardized test to assess proficiency in Spanish, offered by the Spanish government. 


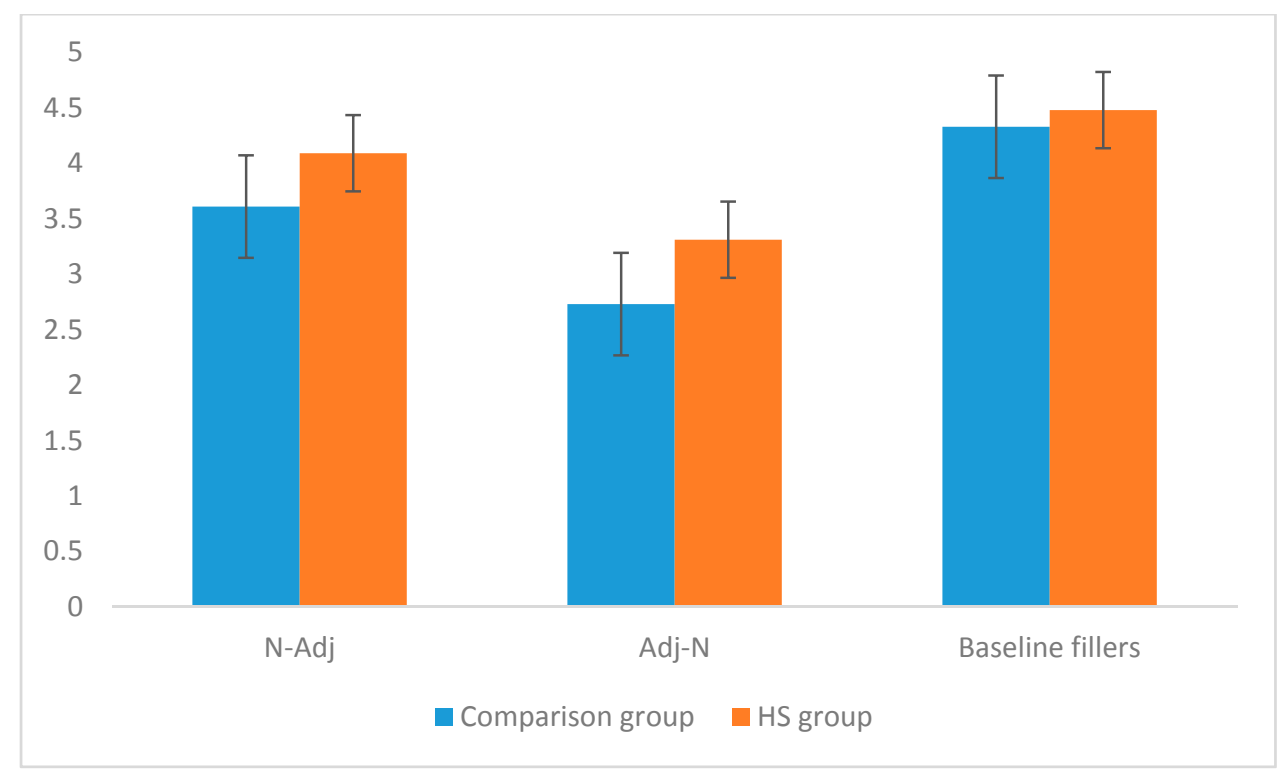

Figure 1. Average ratings for N-Adj, Adj-N and baseline fillers by group.

Figure 2 breaks down the results by Group, Position (prenominal or postnominal adjective), and Adjective-type (i.e., whether the adjective was ambiguous like habilidoso 'handy', excelente 'excellent' or mostly restrictive like rojo, 'rojo'). Let us first look at the comparison group patterns. This group ranked restrictive-only adjectives in a postnominal position highest, followed by ambiguous adjectives in a postnominal position. Additionally, they rated ambiguous adjectives in a prenominal position higher than restrictive-only adjectives in prenominal position, as expected from the traditional description of Romance languages.

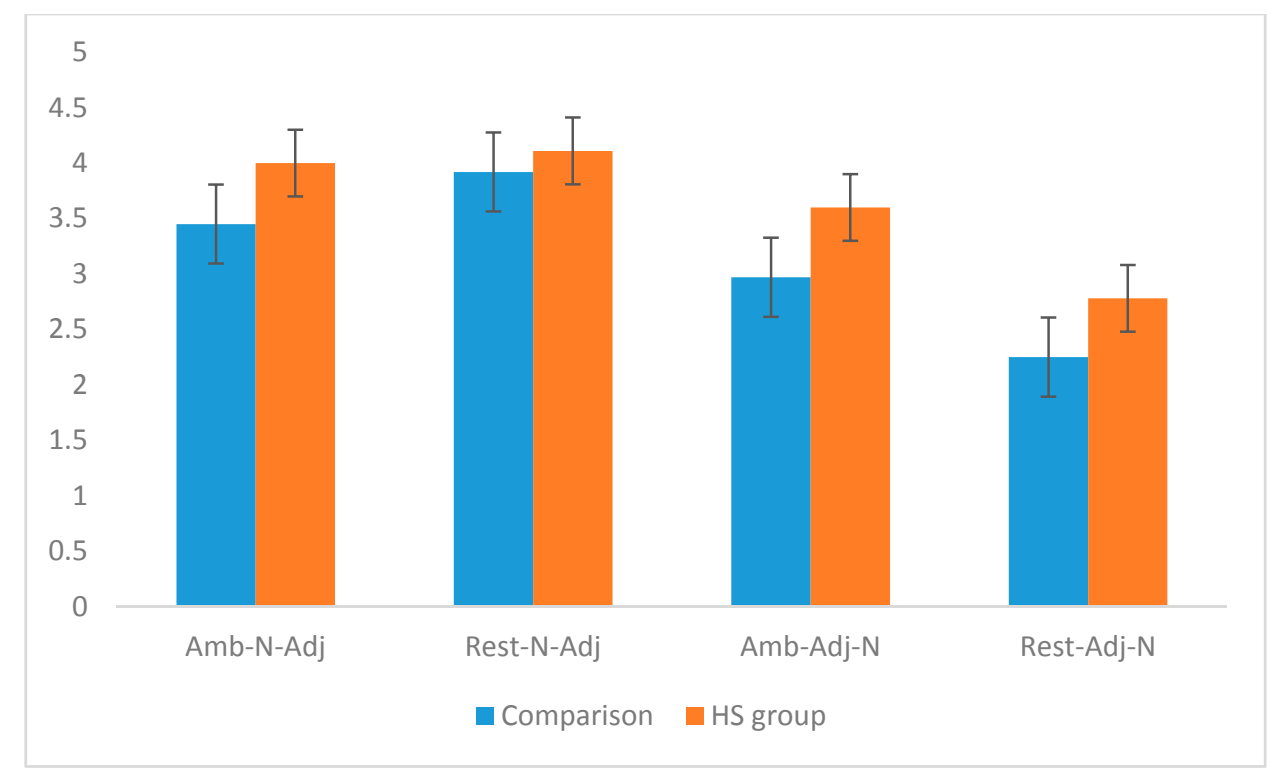

Figure 2. Mean ratings by Adjective-type, Position, and Group.

The HS group showed a similar pattern: on average, they rated prenominal adjectives lower than postnominal ones, and they rated restrictive adjectives in a prenominal position the lowest. In general, the range of ratings across categories was closer than the range of ratings that the comparison group gave. This suggested a less sharp sensitivity to the interpretation-position correlation than for the comparison group. 
A linear regression model was fit (as implemented using the $\mathrm{lm}$ command in the $\mathrm{R}$ statistical software, version 3.4.3 R Core Team 2017) to test if the adjective position, interpretation, and group, had an effect on rating. The traditional 0.05 criterion of statistical significance was employed for all tests. Statistical significance of adjective position, interpretation, and group, and their interactions was assessed using the hierarchical partitioning of variance via nested model comparisons. There was a significant interaction between the adjective position and interpretation $(F(1)=32.27, p<0.0001)$. The model explained $13 \%$ of the variance.

\section{Discussion}

The analyses of adjectives that I presented earlier observed that certain adjective-noun orders were default and others were marked. It also correlated adjective position with semantic interpretation. More specifically, for English, the marked postnominal position was semantically restricted, whereas for Spanish, it was the prenominal position that was restricted.

The linear regression statistics found no statistically significant interaction between group and position, which suggested that HS speakers and the comparison group had similar rating patterns for adjective order, confirming the first hypothesis in (15). Figure 1 reflects this conclusion, since the N-Adj items were rated higher by both groups on average (4.09 for HS speakers and 3.61 for the comparison group), than the Adj-N items (3.31 for HS speakers and 2.73 for the control group). Assuming that speakers rate default options higher than marked options, this suggested that the N-Adj was the default and the Adj-N was the marked option for both groups.

Hypothesis 2 in (16) correlates interpretation and position, and in particular, we expected HS speakers to have a more semantically restricted interpretation in the prenominal position compared to the postnominal one. Recall that the context of the task set up the stage for a restrictive interpretation of the adjective, as shown again in example (19). ${ }^{10}$ Given this context, we expected a higher rating for postnominal adjectives, namely example (19)a, because only postnominal adjectives could be interpreted restrictively.

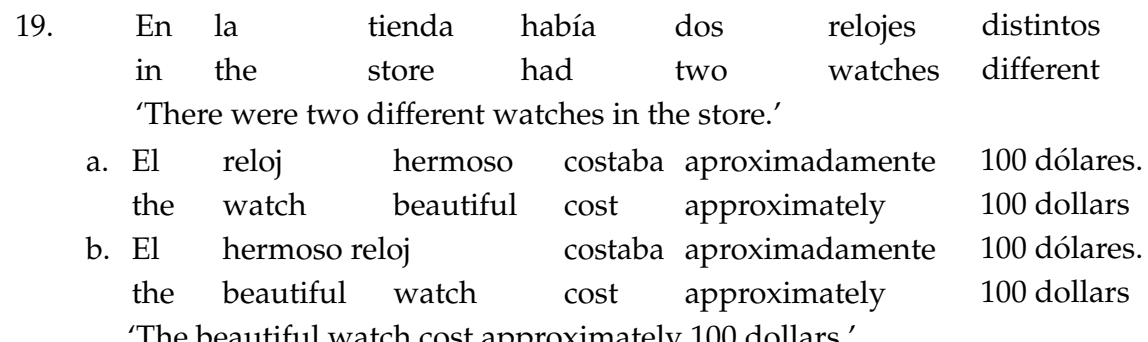

For adjectives that are inherently intersective (color, nationality), and tend to have a restrictive interpretation, the N-Adj order should be rated higher, because they tend to be unacceptable in the prenominal position regardless of the context. Ambiguous adjectives, on the other hand, should also be rated higher in the N-Adj order, but not because of the inherent meaning of the adjective, but because of the context.

The fact that position and interpretation had a statistically significant interaction confirmed that both groups were sensitive to which interpretations were available in each position. On the other hand, since group, position, and interpretation did not show a statistically significant interaction (nor did group and position or group and interpretation), we could conclude that both groups had similar rating patterns with respect to position and interpretation, suggesting that the hypotheses in (16) were also confirmed.

10 Each of the options was rated independently, so participants did not compare them to each other. 
The results presented in Figure 2 reflect these conclusions. Both HS and comparison speakers rate unambiguously restrictive adjectives in postnominal positions higher $(M=3.81$ and $M=3.92$, respectively) than in prenominal positions ( $M=2.78$ and $M=2.25$, respectively), as we would expect from hypothesis (16)a. Both groups also rated ambiguous adjectives higher in the postnominal position ( $M=4$ and $M=3.45$, respectively) vs. prenominal position $(M=3.69$ and $M=2.97$, respectively), as we would expect from hypothesis (16)b.

From a syntactic point of view, these results were consistent with Cinque's proposal for Romance languages, both for the comparison speakers and for the HS group. Specifically, this NP raises to FP4, and FP4 raises above FP1, as seen in example (20).

20. Spanish

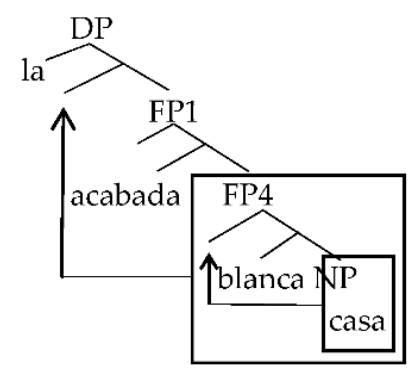

In sum, the HS and the comparison groups seemed to have similar rating patterns that resulted from similar structural representations. However, some of the ratings need additional discussion, which I will discuss next.

\section{Individual Variation}

The results above suggested an overall similarity between HS speakers and the comparison group; however, they raised at least two questions. First, why do HS speakers rate ambiguous prenominal adjectives so high (3.6)? Given the context, this is somewhat unexpected. Although this average rating is lower than that of the baseline (4.48), it is still much higher than that of restrictive adjectives in a prenominal position (2.78). One possible interpretation of these results is that HS speakers perform a process of accommodation as follows: ambiguous adjectives are possible in a prenominal position, but only under the non-restrictive interpretation, which is in principle incompatible with the context. Thus, it is possible that HS speakers are willing to accommodate the context to the sentence, so despite the context in example (19) that presents two clocks, the speaker takes hermoso reloj 'beautiful clock' to state a property of a uniquely salient clock.

Second, HS speaker's ratings for restrictive prenominal adjectives were higher than one would expect, given the preceding discussion, and this may be the result of individual speaker variation, (cf. Rothman et al. 2010). A closer look at the individual ratings for this condition suggested that there were three different groups of speakers: high raters (above 4), low raters (below 2.8), and middle raters (between 2.8 and 4). Low raters were completely consistent with monolingual Spanish speakers, i.e., given the context, they rated restrictive prenominal adjectives as ungrammatical. Conversely, high raters seemed more consistent with the Germanic parameter (more on this below). ${ }^{11}$ The middle group did not lend itself to a straightforward explanation, i.e., it is possible that they had a higher threshold for ungrammaticality (i.e., 3 was the de facto bottom of the scale for them).

Table 1 presents the results for the middle raters. The first five participants (P6, P13, P7, P17, P19) made systematic distinctions between orders in some or all of the categories, whereas P16 and P22 did

11 Participants whose mean was above 4 for these questions did not systematically show higher ratings in other items, so this pattern does not seem like a task effect. 
not. Thus, for the first group, we could argue that the scale was biased towards higher ratings, so that, for P6, 2.8 was the lowest rating for these items, and 4.3 was the most acceptable one. P17's lowest rating was 3.4 and the highest one was 4.8 .

Table 1. Average ratings for participants with high ratings for restrictive postnominal adjectives.

\begin{tabular}{ccccccc}
\hline Participant & Adj-N & N-Adj & Rest_Adj-N & Rest_N-Adj & Amb_Adj-N & Amb_N-Adj \\
\hline P6 & 2.9 & 3.3 & 2.8 & 4.3 & 2.8 & 3 \\
P13 & 4.5 & 4.3 & 3.8 & 5 & 5 & 4 \\
P7 & 3.3 & 4.8 & 3.4 & 5 & 3.4 & 4.9 \\
P17 & 3.7 & 4.3 & 3.4 & 4.8 & 3.8 & 4.3 \\
P19 & 3.7 & 3.7 & 3.2 & 4.5 & 3.8 & 3.4 \\
P16 & 3.2 & 3.9 & 3.2 & 3.8 & 3.1 & 4 \\
P22 & 3.2 & 3.5 & 3.2 & 3.3 & 3.5 & 4 \\
\hline
\end{tabular}

P16 and P22 seemed to be different in the sense that they did not make systematic distinctions between the different items, and those distinctions tended to be smaller (cf. Stadthagen-González et al. 2018), although generally in the direction that we would expect, i.e., they preferred postnominal adjectives over prenominal ones, in particular, ambiguous and restrictive adjectives in a postnominal over a prenominal position.

Assuming that these two participants were sensitive to the context set up by the first sentence in the experiment, these differences would suggest that they were interpreting the adjectives restrictively, even when they were prenominal, much like English does. Postnominal ones, on the other hand, were also interpreted restrictively, much like monolingual Spanish does. In the literature on bilingualism and historical change, this state of affairs has been interpreted in two ways: as simultaneous, competing grammars (Roberts 1993; Toribio 2000), or as the grammatical convergence of functional features (cf. Sánchez 2003).

Here, I would like to suggest an alternative proposal by extending the optimal solution for conflicting word orders involves the deletion of different copies (cf. Camacho and Kirova 2018). Chomsky (1993) revives the copy theory of movement, which reformulates movement as follows: in a structure like example (21)a, movement is defined as re-merging B to a different position, as in example (21)b, and subsequently deleting one of the copies at spell-out, as in example (21)c.
21. a. $[\mathrm{A} \mathrm{B}]$
b. $[\mathrm{B}[\mathrm{A} B]]$
c. $[\mathrm{B}[\mathrm{A} B]]$

The principles that determine which copy is deleted are still being actively investigated (cf. Corver and Nunes 2007, for a summary). Some may involve interpretive requirements at the LF, whilst others are related to the linearization of the syntactic structure (PF), and the cases at hand would seem to follow under this rubric. Bošković and Nunes (2007) group a subset of these cases under the label of P(ronounce)L(ower)C(opy), a principle the extends Franks' (1999) proposal that in chains involving two or more copies, the higher copy (the head of the chain) is realized and the lower copies are deleted unless pronouncing the higher copy would lead to a PF violation. In other words, the default spell-out rule would be to pronounce the higher copy, but this general strategy can be overridden by PF restrictions. Bošković and Nunes (2007) showed several instances where PF principles required a lower copy pronunciation. For example, Romanian requires multiple wh-fronting, as illustrated in example (22), where the two wh-words must appear at the beginning of the clause. Following Bošković (2002), they suggested that example (22)a has the structure in example (22)c, with copy + deletion of the lower copy. However, when the two wh-words are homophonous, then one of them must remain in situ, as seen in examples (22)a vs. b. 
22
a.

\begin{abstract}
Cine
\end{abstract}
ce
precede?
b.
who
what
precedes
*Cine
precede
ce?
who
precedes what
'Who precedes what?'

c.

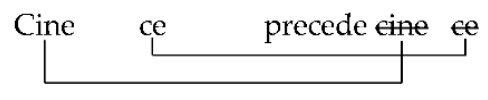

23.

$\begin{array}{llll}\text { a. } & \text { Ce } & \text { precede } & \text { ce? } \\ & \text { what } & \text { precedes } & \text { what } \\ \text { b. } & { }^{*} \mathrm{Ce} & \text { ce } & \text { precede } \\ & \text { what } & \text { what } & \text { precedes } \\ & \text { 'What precedes what?' } & \end{array}$

c.

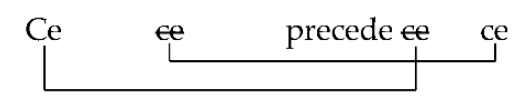

For (23)a, Bošković (2002) argues that the higher copy is deleted, as in example (23)c. This is due to a PF rule that restricts phonologically identical adjacent material, which would be the result in (23)b if the lower copy were deleted.

Assuming this version of copy and deletion theory, NP-movement involves remerging NP to a higher position, as in example (24)a, with subsequent deletion of one of the two copies (along the lines of Cinque's analysis). For monolingual Spanish, and for HS speakers, that pattern like the comparison group (let us call them HS1), the lower copy of the NP is subsequently deleted, as in (24)b. For the HS speakers whose ratings follow the monolingual pattern, but who rate prenominal items higher (HS2), copy/movement takes place as in monolingual Spanish, but the higher copy of the NP is deleted, as in (24)c. Finally, for HS speakers who do not show a clear preference for postnominal adjectives (HS3), we have two possible options: first, no movement is triggered, just as in English and this predicts the linear order Adj-NP. Second, it is possible that they do have raising, but they have a higher tendency to delete the higher copy of the NP than the group HS2. ${ }^{12}$

Thus, the HS speaker grammar is like the monolingual Spanish in having an overt movement, but for some speakers, it differs in having a higher copy deletion.

24. a. NP movement b. Low copy deletion (monolingual Spanish, HS1) c. High copy deletion (HS2)
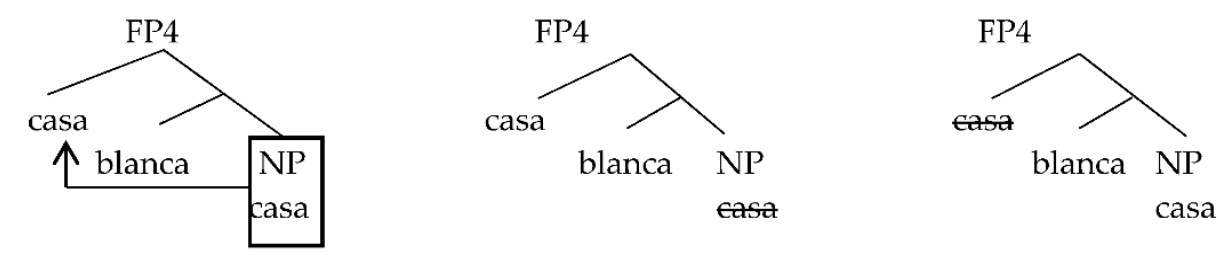

12 Thanks to anonymous reviewer 1 for suggesting this possibility. Anonymous reviewer 2 asked whether there was a way to tease apart these two options. One possibility would be to test responses to intensional, prenominal adjectives like mero 'mere', presunto 'alleged' vs. those that are pre or post-nominal. Presumably, one would find a strong preference for prenominal positions with intensional ones than with ambiguous ones. 
Following our discussion of Bošković and Nunes (2007), the strategy in example (24)b is the default one, because the head copy is pronounced, although this result is not compatible with the English grammar. Arguably, such a strategy is associated with higher-proficiency bilinguals.

The result in example (24)c, on the other hand, involves pronunciation of the lower copy, which is the marked strategy. However, the result is "convergent" with English grammar in that it respects the superficial word order of English (e.g., white house). At the same time, it converges with monolingual Spanish grammar, in the sense that it is structurally identical with that grammar. One possible motivation for pronouncing the lower copy is suggested in (Camacho and Kirova 2018), who argue that this convergent strategy minimizes the processing costs of having two grammars simultaneously activated.

As far as is known, the notion of copy deletion has not been applied to account for the properties of bilingual grammars in the way proposed in this study. However, the results from Bley-Vroman and Yoshinaga (2000) study of the acquisition of English multiple wh-questions by Japanese L2 speakers could be partially interpreted in the same way proposed in this study (cf. also Zakarazadeh and Moslemi's (2014) replication with Persian L2 speakers of English). In this study, advanced English L2-Japanese L1 speakers rated six questions with different combinations of who and another wh-word (what, where, when, how, and why). For monolingual English, Bley-Vroman and Yoshinaga found a decreasing acceptability pattern that became statistically significant when comparing where vs. when and how vs. why. For Japanese monolinguals, all combinations are highly acceptable. Let us assume that a syntactic condition licenses copy of the wh-words in all Japanese cases, followed by deletion of the lower copy. In English, copying is only possible for argument wh-cases (in a rough approximation), whereas the adjunct cannot be copied, as seen in example (25).

25.

$\begin{array}{lll}\text { Multiple wh-questions } & \text { Syntactic licensing of copy } & \text { Deletion } \\ \text { Japanese: } & \text { Argument + Adjuncts } & \text { Low copy deletion } \\ \text { English: } & \text { Argument } & \text { High copy deletion (adjunct } w h \text { ) }\end{array}$

In the case of L2 English, they also found that the overall rating pattern decreases from what to why, as in monolingual English, in particular, rating differences for what vs. where were significantly different, which we could reinterpret to mean that the English distinction between syntactic licensing of copying for arguments vs. adjuncts is in place. Additionally, Japanese L2 speakers rated all conditions lower than monolinguals with the exception of those involving why. We can attribute this lower rating to the fact that English has a high-copy deletion, which as suggested, is the marked option. While many important details remain to be explained in this reanalysis of Bley-Vroman and Yoshinaga's (2000) results, the overall tendencies seem consistent with the account based on the deletion of different copies and its interaction with markedness.

\section{Conclusions}

The results of this study suggest that HS speakers and a comparison group show similar rating patterns for the position of adjectives in conjunction with their interpretation. Ratings for the N-Adj items were higher than for the Adj- $\mathrm{N}$, and for ambiguous and restrictive adjectives in a postnominal position generally, which follows if interpretations obtain in fixed structural positions, and word order results from NP movement past those positions (Cinque's (2010) analysis). This study also suggested that HS speakers can be divided into three groups: the first group patterns were very similar to the comparison group, where in those cases, the NP moves past the adjective, leaves a copy in its original position, and the lower copy of the NP is deleted. The resulting linear order is NP-Adj. The second group of HS speakers showed similar patterns to the comparison speakers as well, but with slightly higher ratings for preverbal adjectives. For this group, this study argued that the NP was copied higher than the adjective, but the higher NP copy was deleted, resulting in the linear order Adj-NP. Finally, the third group involved HS speakers who did not show a clear preference for postnominal adjectives, and for this group, this study argued for two possibilities: either the NP does not raise, just 
as in English, or they had the same derivation as in group 2, i.e., raising of the NP with systematic deletion of the higher copy. The higher rating for prenominal adjectives would follow, in this case from a preference to delete the higher copy, which makes the linear order compatible with English. This principle to prioritize linear compatibility overrides the default strategy of lower copy deletion.

Funding: This research received no external funding.

Acknowledgments: I wish to thank Ana Teresa Pérez-Leroux, Liliana Sánchez, Roger Schwarzschild, the audience at the University of Toronto Spanish colloquium, the audience at LSRL 2018 (University of Toronto), and two anonymous reviewers for excellent comments that have substantially improved this article.

Conflicts of Interest: The author declares no conflict of interest.

\section{Appendix A}

Experimental items:

Sample presentation:

Context: Íbamos por la calle y nos encontramos varios equilibristas.

Item: El habilidoso equilibrista manejaba hasta 5 pelotas.

Context: Íbamos por la calle y nos encontramos varios equilibristas.

Item: El equilibrista habilidoso manejaba hasta 5 pelotas.

Consultamos con dos médicos distintos sobre un problema de salud.

El excelente médico nos dio un diagnóstico.

El médico excelente nos dió un diagnóstico.

Durante una época, la niña tenía dos amigos distintos.

El imaginario amigo se llamaba Juan Manuel.

El amigo imaginario se llamaba Juan Manuel.

En la universidad había dos profesores muy distintos.

El pretencioso profesor hablaba sobre sus logros.

El profesor pretencioso hablaba sobre sus logros.

En el gimnasio había dos levantadores de pesas distintos.

El musculoso levantador conseguía levantar 250 libras.

El levantador musculoso conseguía levantar 250 libras.

En la tienda había dos relojes distintos.

El hermoso reloj costaba más 100 dólares.

El reloj hermoso costaba más 100 dólares.

En la fábrica había dos carros distintos.

El gran carro costaba más 20 mil dólares.

El carro grande costaba más 20 mil dólares.

Ese día tuve dos ideas muy distintas.

La buena idea resultó muy poco interestante.

La idea buena resultó muy poco interestante.

Durante el viaje visitamos dos muy distintas ciudades.

La vieja ciudad nos pareció bastante bonita.

La ciudad vieja nos pareció bastante bonita.

En el sótano Susana guarda dos cuadros distintos.

El único cuadro es un gran retrato.

El cuadro único es un gran retrato.

En su garaje, Miguel tiene dos bicicletas distintas.

La blanca bicicleta es para la montaña.

El bicicleta blanca es para la montaña.

En mi calle hay dos casas de distintos colores

La roja casa está en la esquina.

La casa roja está en la esquina. 
En el viaje, Ana conoció a dos niños de lugares distintos.

El italiano niño tenía una sonrisa increíble.

El niño italiano tenía una sonrisa increíble.

En ese restaurante venden distintos tipos de sándwiches.

El cubano sandwich siempre está muy bueno.

El sandwich cubano siempre está muy bueno

En mi trabajo hay dos compañeros que hablan distintas lenguas.

El mexicano colega habla siempre en español.

El colega mexicano habla siempre en español.

Distracters

En la librería Juan encontró un libro de matemáticas.

El libro de él costó \$50 dólares.

Su libro costó más de $\$ 50$ dólares.

Este mes, Miguel vendió un automóvil del año pasado.

El automóvil de él costó 9000 dólares.

Su automóvil costó más de 9000 dólares.

En la tienda de muebles, Miguel y Marta comparon unas sillas.

La silla de él tenía rallas blancas.

Su silla tenía rallas negras y blancas.

Esta mañana Juan y Ana donaron unos teléfonos celulares antigüos.

El teléfono de él parecía un I-Phone.

Su teléfono parecía un I-Phone muy extraño.

Durante su visita, Marta compró unas flores de papel.

Las flores de ella tenían pétalos rojos.

Sus flores tenían pétalos de varios colores.

Esta mañana, Ana recibió una invitación a la fiesta.

La invitación de ella tenía un dibujo.

Su invitación tenía varios dibujos muy originales.

Por la tarde, Ana y Antonio hicieron unos platos para una fiesta.

El plato de ella incluía papas asadas.

Su plato incluía unas papas muy ricas.

En vacaciones, Margarita y Andrés pintaron unos cuadros para la escuela.

El cuadro de ella parecía un paisaje.

Su cuadro parecía un paisaje de montaña.

Ayer, Miguel y Andrés hicieron unas invitaciones para la fiesta.

Las invitaciones de ellos iban en sobres.

Sus invitaciones iban en sobres con dibujos.

Esta mañana, Juan y Antonio compraron unas galletas para sus amigos.

Las galletas de ellos tenían mucho chocolate.

Sus galletas tenían pedazos de chocolate amargo.

Anoche, Margarita y Ana vendieron unas entradas para el concierto.

Las entradas de ellas costaron mucho dinero.

Sus entradas costaron grandes canitidades de dinero.

Por la mañana, Marta y Lina buscaron un regalo para sus amigos.

Los regalos de ellas resultaron bastante caros.

Sus regalos resultaron bastante caros y bonitos.

Esta tarde, Marta estaba esperando en la fila del correo.

Una señora estaba esperando delante de ella.

Una señora mayor estaba esperando delante suyo.

Una señora mayor estaba esperando delante suya. 
Por la mañana, Margarita y Ana estaban comprando comida

Un joven estaba sentado delante de ellas.

Un hombre joven estaba sentado delante suyo.

Un hombre joven estaba sentado delante suyas.

Ayer tarde, Juan estaba en la parada del autobús

Un niño chiquito esperaba delante de él.

Un niño chuiquito esperaba aburrido delante suyo.

Hoy Juan y Miguel estaban en la fila del supermercado.

Una niña estaba parada delante de ellos.

Una niña grande estaba parada delante suyo.

Una niña grande estaban parada delante suyos.

Durante la mañana, Julia visitó el museo.

Un anuncio indicaba dónde estaba la entrada.

Un empleado la acompañó durante la visita.

Hoy Juan y Miguel estaban sentados en la primera fila del cine.

La pantalla estaba cerca de los asientos.

La pantalla tenía pintura en la esquina.

\section{Appendix B}

Background questionnaire

1. First language that you learned

2. At what age did you start to learn each language?

3. Current dominant language

4. Language spoken by the majority of people around you

5. Please rate your current overall language ability in each of the following languages $(0=$ poor, 5 = native speaker, Spanish, English)

6. Please rate your current language ability in reading, writing, speaking listening, in each of the following languages ( 0 = poor, 5 = native speaker, Spanish, English)

\section{References}

Abeillé, Anne, and Danièle Godard. 1999. La position de l'adjectif épithète en français: Le poids des mots. Recherches Linguistiques de Vincennes 28: 9-32. Available online: https:/ / www.cairn.info/revue-rechercheslinguistiques-de-vincennes-1999-1-page-2.htm (accessed on 21 November 2016).

Alexiadou, Artemis. 2001. Adjective Syntax and Noun Raising: Word Order Asymmetries in the DP as the Result of Adjective Distribution. Studia Linguistica 55: 217. [CrossRef]

Alexiadou, Artemis. 2014. The syntax of adjectives. In The Routledge Handbook of Syntax. Edited by Andrew Carnie, Yosuke Sato and Daniel Siddiqi. London: Routledge, pp. 89-107.

Anderson, Bruce. 2001. Adjective position and interpretation in L2 French. In Romance Syntax, Semantics and Their L2 Acquisition. Edited by Joaquim Camps and Caroline Wiltshire. Amsterdam: Benjamins, pp. 27-46.

Anderson, Bruce. 2002. The Fundamental Equivalence of Native and Interlanguage Grammars: Evidence from Argument Licensing and Adjective Position in L2 French. Bloomington: Indiana University.

Anderson, Bruce. 2007. Learnability and parametric change in the nominal system of L2 French. Language Acquisition 14: 165-214. [CrossRef]

Anderson, Bruce. 2008. Forms of Evidence and Grammatical Development in the Acquisition of Adjective Position in L2 French. Studies in Second Language Acquisition 30: 1-29. [CrossRef]

Androutsopoulou, Antonia. 2000. On the (in)ability of prenominal attributive adjectives to take complements. In WCCFL 19. Stanford: CSLI Publications, pp. 29-42.

Androutsopoulou, Antonia, Manuel Español-Echevarría, and Philippe Prévost. 2008. On the Acquisition of the Prenominal Placement of Evaluative Adjectives in L2 Spanish. In Selected Proceedings of the 10th Hispanic Linguistics Symposium. Edited by Joyce Bruhn de Garavito and Elena Valenzuela. Somerville: Cascadilla Proceedings Project, pp. 1-12. 
Bello, Andrés. 1847. Gramática de la Lengua Castellana Para el uso de los Americanos. Republished in 1988 by Ramón Trujillo, ed. Madrid: Arco/Libros.

Bernstein, Judy. 1991. DPs in French and Walloon: Evidence for Parametric Variation in Nominal Head Movement. Probus 3: 101-26. [CrossRef]

Bernstein, Judy. 1993a. Topics in the Syntax of Nominal Structure across Romance. Ph.D. dissertation, City University of New York, New York, NY, USA.

Bernstein, Judy. 1993b. The Syntactic Role of Word Markers in Null Nominal Constructions. Probus 5: 5-38. [CrossRef]

Bley-Vroman, Robert, and Naoko Yoshinaga. 2000. The acquisition of multiple wh-questions by high-proficiency non-native speakers of English. Second Language Research 16: 3-26. [CrossRef]

Bolinger, Dwight. 1967. Adjectives in English: Attribution and Predication. Lingua 18: 1-34. [CrossRef]

Bošković, Željko. 2002. On multiple wh-fronting. Linguistic Inquiry 33: 351-83. [CrossRef]

Bošković, Željko, and Jairo Nunes. 2007. The copy theory of movement. A view from PF. In The Copy Theory of Movement. Edited by Norbert Corver and Jairo Nunes. Amsterdam: John Benjamins, pp. 13-74. [CrossRef]

Bruhn de Garavito, Joyce, and Lydia White. 2002. L2 acquisition of Spanish DPs: The status of grammatical features. In The Acquisition of Spanish Morphosyntax: The L1/L2 Connection. Edited by Ana Teresa Pérez-Leroux and Juana M. Liceras. New York: Springer, pp. 153-78.

Camacho, José, and Alena Kirova. 2018. Adverb placement among heritage speakers of Spanish. Glossa 3: 53. [CrossRef]

Chomsky, Noam. 1993. A Minimalist Program for Linguistic Theory. In The View from Building 20. Edited by Ken Hale and Samuel Jay Keyser. Cambridge: MIT Press, pp. 1-52.

Cinque, Guglielmo. 1994. On the evidence for partial N movement in the Romance DP. In Paths towards Universal Grammar. Edited by Guglielmo Cinque, Jan Koster, Jean-Yves Pollock, Luigi Rizzi and Raffaella Zanuttini. Washington: Georgetown University Press, pp. 85-110.

Cinque, Guglielmo. 2010. The Syntax of Adjectives: A Comparative Study. Cambridge: MIT Press.

Corver, Norbert, and Jairo Nunes, eds. 2007. The Copy Theory of Movement. Amsterdam: John Benjamins, pp. 13-74. [CrossRef]

Demonte, Violeta. 1999a. El adjetivo: Clases y usos. La posición del adjetivo en el sintagma nominal. In Gramática Descriptiva de la Lengua Española. Edited by Ignacio Bosque and Violeta Demonte. Madrid: Espasa-Calpe, pp. 129-216.

Demonte, Violeta. 1999b. A Minimal Account of Spanish Adjective Position and Interpretation. In Analyses in Basque and Romance Linguistics. Papers in Honor of Mario Saltarelli. Edited by Jon A. Franco, Alazne Landa and Juan Martin. Amsterdam: Benjamins, pp. 45-76. [CrossRef]

Demonte, Violeta. 2008. Meaning-form correlations and adjective position in Spanish. In Adjectives and Adverbs. Edited by Louise McNally and Chris Kennedy. Oxford: Oxford University Press, pp. 71-100.

Franks, Steven. 1999. Clitics in Slavic. Glossos. Available online: https://slaviccenters.duke.edu/sites/ slaviccenters.duke.edu/files/media_items_files/10franks.original.pdf (accessed on 11 October 2018).

Gess, Randall, and Julia Herschensohn. 2001. Shifting the DP parameter: A study of anglophone French L2ers. In Romance Syntax, Semantics and their L2 Acquisition. Edited by Joaquim Camps and Caroline Wiltshire. Amsterdam: Benjamins, pp. 105-19.

Kamp, Hans, and Barbara H. Partee. 1995. Prototype Theory and Compositionality. Cognition 57: 121-91. [CrossRef]

Laenzlinger, Christopher. 2004. French adjective ordering: Perspectives on DP-internal movement types. Lingua 115: 645-89. [CrossRef]

Lamarche, Jacques. 1991. Problems for $\mathrm{N}^{0}$-Movement to Num-P. Probus 3: 215-36. [CrossRef]

Larson, Richard, and Franc Marusic. 2004. On Indefinite pronoun structures with APs: Reply to Kishimoto. Linguistic Inquiry 35: 268-87. [CrossRef]

Parodi, Teresa, Bonnie Schwartz, and Harald Clahsen. 2004. On the L2 Acquisition of the Morphosyntax of German Nominals. Linguistics 42: 669-705. [CrossRef]

Peirce, Jonathan W. 2009. Generating stimuli for neuroscience using PsychoPy. Frontiers in Neuroinformatics 2: 10. [CrossRef] [PubMed]

Picallo, M. Carme. 1991. Nominals and nominalization in Catalan. Probus 3: 279-316. [CrossRef] 
Ritter, Elizabeth. 1991. Two functional categories in noun phrases. In Perspectives on Phrase Structure: Heads and Licensing. Edited by Susan Rothstein. San Diego: Academic Press, pp. 37-62.

Roberts, Ian. 1993. Verbs and Diachronic Syntax. Dordrecht: Kluwer Academic Press.

Rothman, Jason, Tiffany Judy, Pedro Guijarro-Fuentes, and Acrisio Pires. 2010. On the (Un)-Ambiguity of Adjectival Modification in Spanish Determiner Phrases: Informing Debates on the Mental Representations of L2 Syntax. Studies in Second Language Acquisition 32: 47-77. [CrossRef]

Sánchez, Liliana. 1996. Syntactic Structures in Nominals: A Comparative Study of Spanish and Southern Quechua. Ph.D. thesis, University of Southern California, Los Angeles, CA, USA.

Sánchez, Liliana. 2003. Quechua-Spanish Bilingualism: Interference and Convergence in Functional Categories. Amsterdam: Benjamins.

Shlonsky, Ur. 2004. The Form of Semitic Noun Phrases. Lingua 114: 1465-526. [CrossRef]

Sproat, Richard, and Chilin Shih. 1991. The cross-linguistic distribution of adjective ordering restrictions. In Interdisciplinary Approaches to Language: Essays in Honor of S.-Y. Kuroda. Edited by Carol Georgopoulos and Roberta Ishihara. New York: Springer, pp. 565-93.

Stadthagen-González, Hans, Luis López, Mari Carmen Parafita Couto, and Alejandro Párraga. 2018. Using two-alternative forced choice tasks and Thurstone's law of comparative judgments for code-switching research. Linguistic Approaches to Bilingualism 8: 67-97. [CrossRef]

Toribio, Almeida Jacqueline. 2000. Setting Parametric Limits on Dialectal Variation in Spanish. Lingua 110: $315-41$. [CrossRef]

Zakarazadeh, Adel, and Somayye Moslemi. 2014. Multiple WH-Questions and Their Acceptance by Native \& Non-Native Speakers of English. A Case Study of Iranian B.A. General English Students. International Journal of Engineering Research and Development 10: 13-19.

(C) 2018 by the author. Licensee MDPI, Basel, Switzerland. This article is an open access article distributed under the terms and conditions of the Creative Commons Attribution (CC BY) license (http://creativecommons.org/licenses/by/4.0/). 